DOI: $10.34185 / 1991-7848.2021 .01 .08$

УДК 629.7:658.512.2

L. Molchanov, N. Arendach, Y. Synehin ${ }^{8}$

\title{
STUDY OF THE DESIGNS OF BOTTOM BLOWING DEVICES FOR OXIDATIVE BLOWING IN TEEMING LADLES
}

It is discussed in the article the concept proposed for the production of ultra-low carbon steel, which involves the production of crude steel in basic oxygen furnace followed by oxidative blowing with an oxygen-argon mixture in a teeming ladle to decrease a carbon content in steel to less than $0.03 \%$. The objective of this article is to study the influence of design of the blowing devices, namely, the position and shape of the pores, on the efficiency of metal homogenization in the teeming ladle. Based on the water modeling, the most efficient design of the blowing devices has been selected.

Keywords: steel, homogenization, ultra-low carbon steel, oxidative blowing

\section{Introduction}

Ultra Low Carbon (ULC) steels have good formability and a superior surface quality. These advantages provide their use as automobile panels since the latter half of the 1980s. This automobile panel material is normally produced by cold rolling and annealing after hot rolling, in which hot rolling is usually finished in the austenite region at the elevated temperature [1].

Conventional IF steels which following the introduction of vacuum degassing technology contained carbon in the range of 40-70 ppm and nitrogen in the range of 30-50 ppm. Later, niobium and/or titanium were added to these steels to stabilize the interstitial carbon and nitrogen atoms [1].

Carbon and nitrogen in sheet steel results in higher mechanical properties, age hardening, and deterioration of the r-value (measure of resistance to thinning and drawability). Liquid steel is processed through a vacuum degasser to reduce carbon and nitrogen to levels low enough that the remainder can be "stabilized" by small additions of titanium and niobium [1].

Titanium and niobium are strong carbide/nitride formers, taking the remaining carbon and nitrogen out of solution in liquid iron, after which these latter two elements are no longer available to reside in the interstices between solidified iron atoms. Non-ageing IF steel has no yield point elongation, which means fluting and stretcher strains are never a problem [1].

(C) Molchanov L., Arendach N., Synehin Y., 2021 
The IF steel made using only titanium is very common and is used to produce the best mechanical properties for deep drawing. Also, a very popular type of IF steels is stabilized with both titanium and niobium. The synergy of these two elements allows complete stabilization to be achieved at lower levels of each element. Depending on the relative amounts of titanium and niobium, the steel needs to be annealed at a higher temperature during galvanizing and has slightly inferior mechanical properties to the Ti type [1].

\section{Literature Review}

There are 3 technological routes for the production of ULC steel: 1) smelting of crude steel in an EAF followed by refining in AOD converter; 2) smelting of crude steel in BOF or LBE-converter followed by processing in RH-OB, VOD or VD-OB and 3) LWS-process [2-4]. The third route is not used outside of France [5]. Both technological routes significantly increase the cost of steel through application of additional units for deep decarburization of steel below a critical concentration of 0.03\%. A cheaper alternative to the above-mentioned technologies is smelting of crude steel in BOF to carbon content of $0.03 \%$, followed by oxidative blowing in a teeming ladle with oxygen-argon mixture [6].

Important indicators for the implementation of the proposed technology are the durability of the blowing devices and the mixing time of the metal in the ladle. The high durability of blowing devices can be achieved by a rational blowing mode and gases flow rates. The mixing time depends of many factors, including the design of the blowing devices, their location, the blowing mode, etc. [6].

It has been carried out number of studies aimed to determine the optimal location of the blowing devices and blowing modes [7-13]. But the effect of pores location and type of porosity in the blowing devices on the averaging mixing time still remains unexplored.

The aim of the study is to determine the effect of pores location in the blowing devices on the mixing time.

\section{Material and methods}

Investigation of the pores shape effect on the mixing time is possible by two methods: 1) mathematical modeling using special commercial programs [8-11] and 2) physical modeling on water models [8, 10, 12-14]. In the present study, the second method has been used, which has been successfully applied in previous studies [6-8, 
10, 12-14]. Estimation of mixing time during physical modeling on water models is possible in three ways: temperature, optical, and chemical (conductive) [15]. Since the temperature method has a high inertness, and the results obtained with the conductive method can differ depending on the location of the electrodes in the ladle model, an optical method has been chosen to estimate the mixing time, which has a sufficiently high accuracy and visibility.

The object of the study was a unit cell mixing of the teeming ladle of $250 \mathrm{t}$ capacity, in which the distribution of the additive occurs. According to the principles of similarity theory, the gas flow rate can be described by the dimensionless volumetric flow rate [13] and the mixing time by the modified homochromous number [6]

$$
\begin{aligned}
& Q=\frac{q}{\sqrt{g \cdot d^{5}}}, \\
& H o^{\prime}=\frac{g \cdot \tau^{2}}{d},
\end{aligned}
$$

where $\mathrm{q}$ - gas flow rate; $\mathrm{g}$ - acceleration of gravity; $\mathrm{d}$ - diameter of porous plug; $\tau$ - mixing time.

By using the linear scale of the model, it can be determined from formula (1) the gas flow rate for the model, as well as the homogenization time for the prototype

$$
\begin{gathered}
q_{m}=q_{p}\left(\frac{d_{m}}{d_{p}}\right)^{2.5}, \\
\tau_{p}=\tau_{m} \sqrt{\frac{d_{p}}{d_{m}}} .
\end{gathered}
$$

Table 1

Parameters for prototype and model

\begin{tabular}{|l|l|l|}
\hline Parameter & Prototype & Model \\
\hline Fluid level, m & 3,768 & 0,45 \\
\hline Diameter of porous plug, m & 0,120 & 0,014 \\
\hline Gas flow rate, l/min & $100-500$ & $0,49-2,46$ \\
\hline Usual processing time, min & 10 & 3,5 \\
\hline Q number & $0,11-0,53$ & $0,11-0,57$ \\
\hline
\end{tabular}

For the experiment, an experimental facility (Fig. 1) was assembled on a 1:8 scale, consisting of a compressor 1 that pumps air into the receiver 2 , which is 
necessary for maintenance of constant pressure and smooth regulation by valve 4 . A pressure gauge 3 is installed to measure air pressure and a float-type area flowmeter 5 PM-0.63 to measure its flow rate. As a model of a unit cell of mixing, a cylindrical tank 6 of acrylic plastic was used. It consists of a chamber and a socket in which a model of the porous plug was installed. Specifically, for the experiment, porous plug with round pores (4 pores of $1 \mathrm{~mm}$ in diameter), rectangular (4 parallel slots $5 \times 1 \mathrm{~mm}$ in size and spaced $1 \mathrm{~mm}$ apart) and with non-oriented porosity were made. To make a high-quality video, the model was installed in the dark chamber 9, which reduces the light glare on the model walls. Artificial lighting allows getting a directed beam of light.
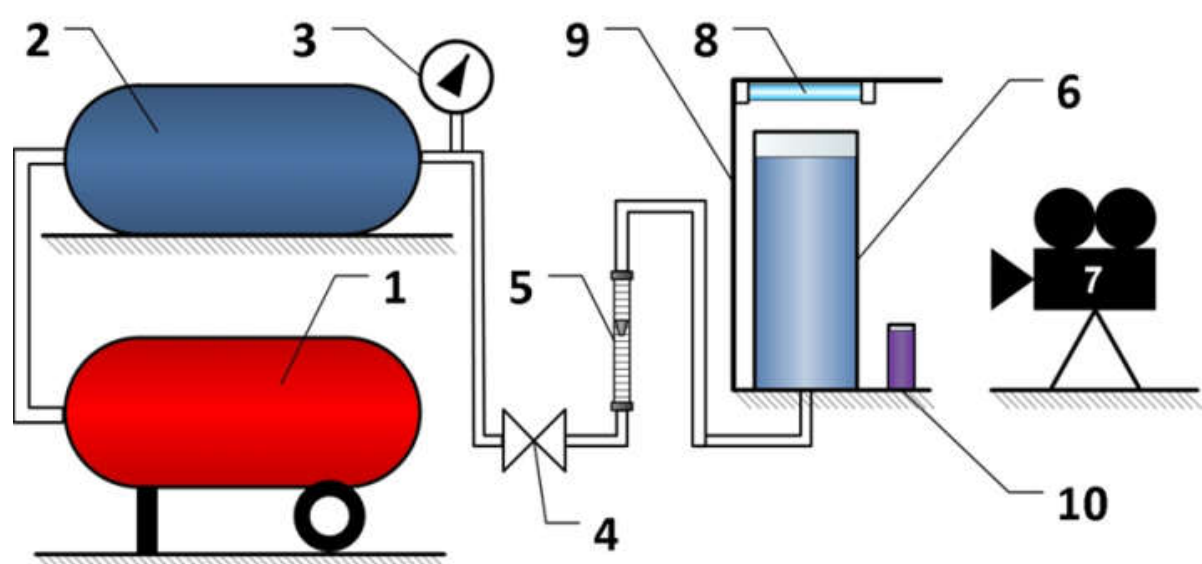

Figure 1 - General scheme of the experimental facility: 1 - compressor; 2 - receiver;

3 - pressure gauge; 4 - valve; 5 - float-type area flowmeter PM-0.63;

6 - the model of an elementary mixing cell; 7 - video camera; 8 - a lamp;

9 - the dark chamber; 10 - control sample

As a tracer imitating chemical heterogeneity of the melt, we used a $30 \%$ aqueous solution of $\mathrm{KMnO}_{4}$, in an amount of $100 \mathrm{ml}$. A tracer was poured at the top of the model. The completion of melt homogenization was judged by approximating the color intensity of the solution to the color of a $3.5 \% \mathrm{KMnO}_{4}$ aqueous solution installed in a transparent container on the other side of the transparent model.

\section{Results}

Using the video, the time was estimated for which the entire volume of liquid reached a uniform color, the same as the color of the control sample. Frames corresponding in time to $0,2,3,4$, and 5 seconds after adding a tracer for each design of the blowing devices are shown in Fig. 2. To obtain adequate results, 5 series of experiments were carried out using each design of the blowing devices. 


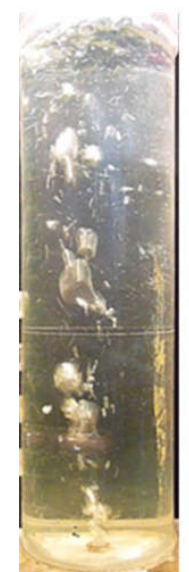

a)

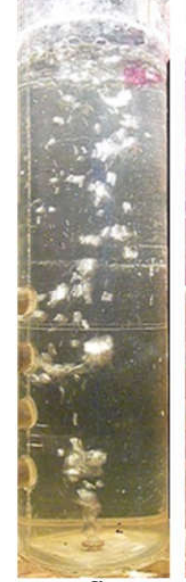

f)

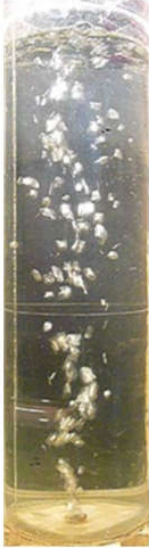

k)

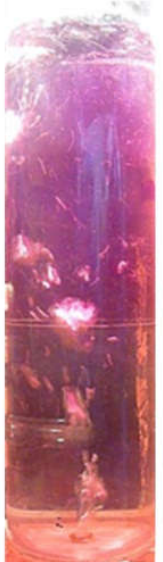

b)

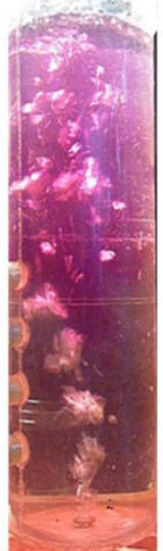

g)

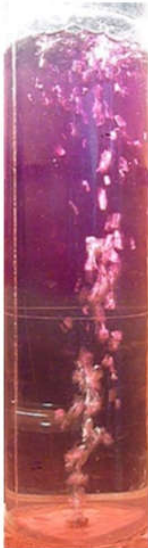

I)

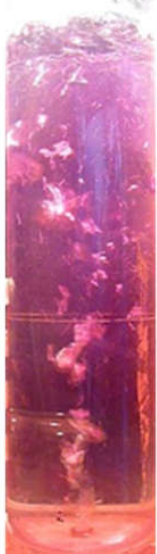

c)

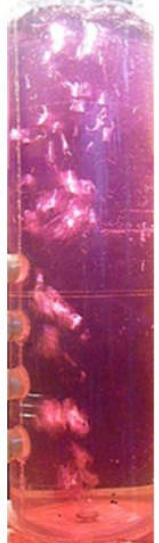

h)

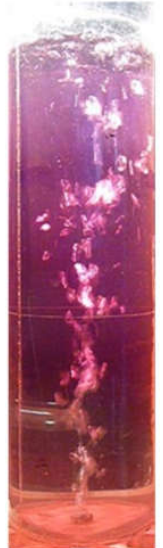

m)

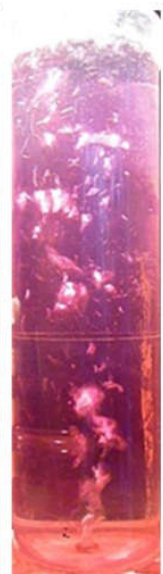

d)

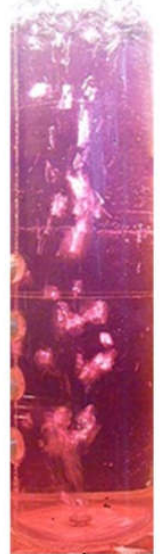

i)

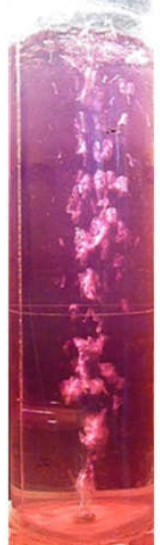

n)

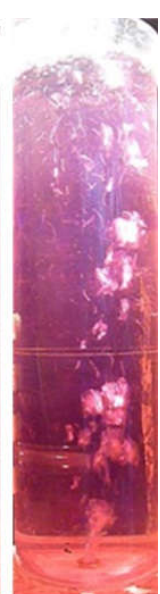

e)

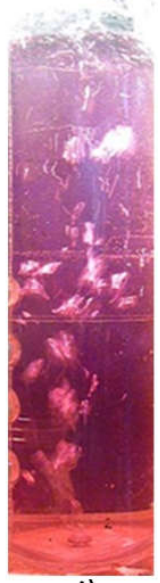

j)

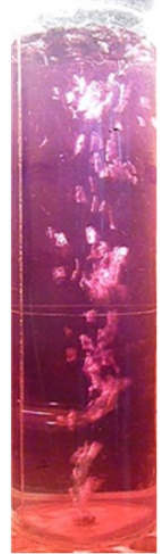

o)

Figure 2 - Change in water color right after adding a tracer (a, f, k), after $2 \mathrm{~s}(\mathrm{~b}, \mathrm{~g}, \mathrm{l})$, $3(\mathrm{c}, \mathrm{h}, \mathrm{m}), 4 \mathrm{~s}(\mathrm{~d}, \mathrm{i}, \mathrm{n})$ and $5 \mathrm{~s}(\mathrm{e}, \mathrm{j}, \mathrm{o})$ when using blowing units with pores of round (a-e) and rectangular (f-j) shapes and with non-oriented porosity (k-o)

\section{Discussion}

Figure 3 shows a comparison of the average tracer mixing time in water. As can be seen from the comparison, blowing devices with non-directional porosity provide the shortest mixing time. This is probably due to the larger total specific area of the bubbles that form on the surface of the blowing device with non-oriented porosity. 


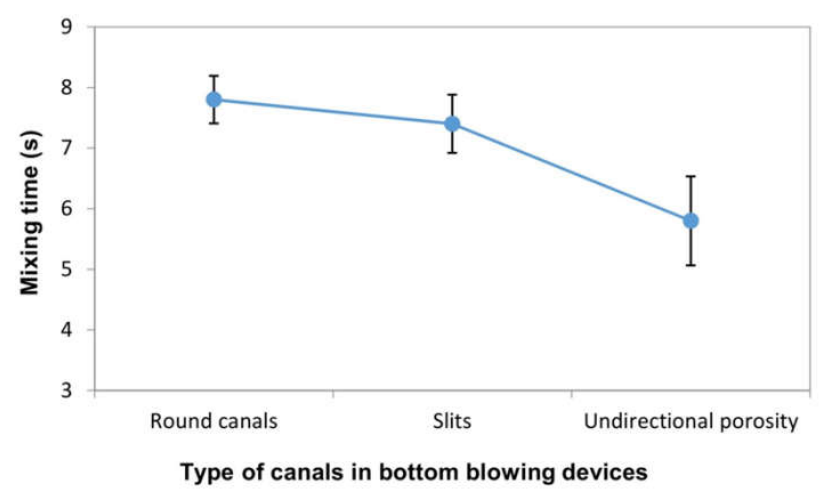

Figure 3 - Comparison of mixing time when using porous devices of various designs

At the same time, plugs with non-oriented porosity have two significant disadvantages [16]. The first is the rapid wear of the working part of the blowing devices in contact with the metal. The second disadvantage is their low throughput. The last one is eliminated when using plugs with slot porosity. However, when using such plugs, there is a risk of deep infiltration of liquid metal into the slots during an uneven argon supply.

\section{Conclusions}

Using the method of physical modeling in a water model, it has been found that the best results on mixing the chemical composition of liquid metal in a ladle show blowing devices with non-oriented porosity. They are ideally suited for oxidative blowing in a teeming ladle with an argon-oxygen mixture necessary for the production of ultra-low carbon steel with an oxygen content of less than $0.03 \%$. The aim of further research is the development of the design of the mixing chamber of the blowing device, in which oxygen and argon are pre-mixed before being blown into the liquid metal.

\section{REFERENCES}

1. Ultra low carbon interstitial free steels. (n.d.). Retrieved December 04, 2020, from https://www.totalmateria.com/page.aspx?ID=CheckArticle\&site=kts \&LN=ES\&NM=449

2. Yu Huang, Guo-guang Cheng, Qiming Wang, Shi-jian Li \& Wei-xing Dai (2019). Mathematical model for decarburization of ultra-low carbon steel during $\mathrm{RH}$ treatment, Ironmaking \& Steelmaking, doi: 10.1080/03019233.2019.1567999.

3. Wimer H.E. (1998). Obzor tekhnologiy i agregatov kovshovoy metallurgii (Overview of Ladle Metallurgy Technologies and Units). Чёрные металлы (Ferrous Metals), No. 6, pp. 26-28 (in Russian).

4. Brachet D., Gatellier C., Zbaczyniak Y., Nadif M., Chapellier Ph., Leclercq A. (1993). Metallurgical comparison of various production routes for low and ultra-low carbon steels, Revue de Metallurgie, Vol. 90, No. 1, pp. 77-83, doi: 10.1051/metal/199390010077

5. Sujay Kumar Dutta, Yakshil B. Chokshi (2020). Basic Concepts of Iron and Steel Making. Singapore, Springer, doi: 10.1007/978-981-15-2437-0

6. Molchanov L., Sheremeta N., Synehin Y. (2018). Study of efficiency of liquid steel homogenization with blowing through blocks of various designs. Theory and Practice of Metallurgy, doi: 10.34185/tpm.6.2018.10 
7. Haiyan Tang, Jinwen Liu, Shuo Zhang, Xiaochen Guo, Jiaquan Zhang (2019). A novel dual plugs gas blowing mode for efficient ladle metallurgy, Ironmaking \& Steelmaking, doi: 10.1080/03019233.2019.1576270

8. Ramasetti E., Visuri V.-V., Sulasalmi P., Palovaara T., Gupta A. K., Fabritius T. (2019). Physical and CFD Modeling of the Effect of Top Layer Properties on the Formation of Open-Eye in Gas-Stirred Ladles With Single and Dual-Plugs, Steel Research International, doi: 10.1002/srin.201900088

9. Liu H., Qi Z., Xu M. (2011). Numerical simulation of fluid flow and interfacial behavior in threephase argon-stirred ladles with one plug and dual plugs, Steel Research International, doi: 10.1002/srin.201000164

10.Liu W., Tang H., Yang S., Wang M., Li J., Liu Q., Liu J. (2018). Numerical simulation of slag eye formation and slag entrapment in a bottom-blown argon-stirred ladle, Metallurgical and Materials Transactions B, doi: 10.1007/s11663-018-1308-6

11.Chen Y., Pang Y., Zhang X. (2011). Numerical study on effects of molten steel flow about different blowing argon position in ladle furnace, Advanced Materials Research, doi: 10.4028/www.scientific.net/AMR.146-147.1031

12.Hai-yan Tang, Jingshe li, Cui-hong Xie, Shufeng Yang, Kai-ming Sun, De-song Wen (2009). Rational argon stirring for a 150-t ladle furnace, International Journal of Minerals Metallurgy and Materials B, doi: 10.1016/S1674-4799(09)60068-6

13. Krishnapisharody K, Irons G.A. (2006). Modeling of slag eye formation over a metal bath due to gas bubbling, International Journal of Minerals Metallurgy and Materials B, doi: 10.1007/s11663-0060058-z

14. Mandal J, Patil S., Madan M., Mazumdar D. (2005). Mixing time and correlation for ladles stirred with dual porous plugs, Metallurgical and Materials Transactions B, doi: 10.1007/s11663-0050039-7

15. Yeronko S.P., Bykovskykh S.V. (1998). Fizychne modelyuvannya protsesiv pozapichnoyi obrobky ta rozlyvannya stali (Physical modeling of the processes of ladle processing and casting of steel). Kyiv, Tekhnika (in Ukrainian).

16.Egorov, I.V., Matvienko, A.S. (2011). Blow plugs from OOO Keralit. Refractories and Industrial Ceramic, Vol. 51, No. 6, pp. 411-415, doi: 10.1007/s11148-011-9339-4

Received 19.01.2021.

Accepted 29.01.2021.

УДК 669

Л.С. Молчанов, Н.А. Арендач, Є.В. Синегін

\section{ДОСЛІДЖЕННЯ КОНСТРУКЦІЇ ДОННИХ ПРОДУВОЧНИХ ПРИСТРОЇВ ДЛЯ ОКИСЛЮВАЛЬНОЇ ПРОДУВКИ У СТАЛЕРОЗЛИВНИХ КОВШАХ}

у статті обговорюється концепція, запропонована для виробництва ультронизьковуглецевої сталі, яка передбачає виробництво сирої сталі в кисневому конвертері з подальшою окислювальною продувкою сумішшю кисню та аргону в сталерозливному ковші для зменшення вмісту вуглецю в сталі до менш ніж 0,03\%. Висока ефективність запропонованої технології можлива лише за умови інтенсивного протікання процесу зневуглецьовування металу, який складається 3 трьох ланок: підведення реагентів до газової бульбашки, хімічна взаємодія реагентів на міжфазній поверхні і відведення від неї продуктів реакції. За низької концентрації вуглецю в металі лімітуючою ланкою процесу стає масопереніс вуглецю до міжфазної поверхні, який може бути інтенсифікований перемішуванням розплаву. Завдання цієї статті полягає у вивченні впливу конструкції продувочних пристроїв, а саме розташування та форми пір, на ефективність гомогенізації металів у сталерозливному ковші. Для 
вирішення поставленої задачі було обрано метод фізичного моделювання на водній прозорій моделі. Розглянуто продувочні пристрої з круговим отвором, шпариною та ненаправленою пористістю. Для проведення фізичного моделювання за теоремою Букінгема було обрано числа подоби для описання досліджуваного процесу. Зокрема запропоновано використовувати безрозмірну об'ємну витрату i модифікований критерій гомохронності. Використовуючи метод фізичного моделювання на водяній моделі, було встановлено, що найкращі результати з усереднення хімічного складу рідкого металу в ковші демонструють продувочні пристрої 3 неорієнтованою пористістю. Вони ідеально підходять для окисного продування в переповненому ковші сумішшю аргону та кисню, необхідною для виробництва наднизьковуглецевої сталі 3 вмістом кисню менше 0,03\%. Метою подальших досліджень $є$ розробка конструкції змішувальної камери продувного пристрою, в якій кисень і аргон попередньо змішуються перед вдуванням у рідкий метал.

Ключові слова: сталь, гомогенізація, наднизьковуглецева сталь, окисне продування.

UDC 669

L. Molchanov, N. Arendach, Y. Synehin

\section{STUDY OF THE DESIGNS OF BOTTOM BLOWING DEVICES FOR OXIDATIVE BLOWING IN TEEMING LADLES}

It is discussed in the article the concept proposed for the production of ultra-low carbon steel, which involves the production of crude steel in basic oxygen furnace followed by oxidative blowing with an oxygen-argon mixture in a teeming ladle to decrease a carbon content in steel to less than $0.03 \%$. High efficiency of the proposed technology is possible only under the intensive process of metal decarburization, which consists of the three stages: supply of reagents to the gas bubble, chemical interaction of reagents on the interfacial surface and removal of reaction products. At low carbon concentrations in the metal, the limiting link of the process is carbon mass transfer to the interfacial surface, which can be intensified by melt stirring. The objective of this article is to study the influence of design of the blowing devices, namely, the position and shape of the pores, on the efficiency of metal homogenization in the teeming ladle. Blowing devices with a circular hole, a slit and undirectional porosity were considered. To perform physical simulation by Buckingham's theorem, similarity numbers were chosen to describe the considered process. In particular, it is proposed to use dimensionless volume flow and a modified homochronicity number. Based on the physical simulation on the "water" model, it was found that the best results of homogenization of the chemical composition of the liquid metal in the teeming ladle show blowing devices with undirected porosity. They are ideal for oxidative purging in a crowded ladle with a mixture of argon and oxygen required for the production of ultra-low carbon steel with an oxygen content of less than $0.03 \%$. The purpose of further research is to develop the design of the mixing chamber of the purge device, in which oxygen and argon are pre-mixed before injection into the liquid metal.

Keywords: steel, homogenization, ultra-low carbon steel, oxidative blowing 
Молчанов Лавр Сергійович - к.т.н., завідувач відділом фізико-технічних проблем металургії сталі, Інститут чорної металургії ім. 3.І. Некрасова Національної академії наук України.

Арендач Наталя Анатоліївна - аспірантка кафедри металургї чавуну і сталі, Національна металургійна академія України.

Синегін Євген Володимирович - доцент, к.т.н., доцент кафедри металургії чавуну і сталі, Національна металургійна академія України.

Молчанов Лавр Сергеевич - заведующий отделом физико-технических проблем металлургии стали, Институт черной металлургии им. 3.И. Некрасова Национальной академии наук Украины.

Арендач Наталья Анатольевна - аспирантка кафедры металлургии чугуна и стали, Национальная металлургическая академия Украины.

Синегин Евгений Владимирович - доцент, к.т.н., доцент кафедры металлургии чугуна и стали, Национальная металлургическая академия Украины.

Molchanov Lavr - PhD, Head of the Department of Physical and Technical Problems of Steel Metallurgy, Z. I. Nekrasov Iron \& Steel Institute of NAS of Ukraine.

Arendach Natalia - PhD Student, Department of Iron and Steel Metallurgy, The National Metallurgical Academy of Ukraine.

Synehin Yevhen - PhD, Associate Professor, Department of Iron and Steel Metallurgy, The National Metallurgical Academy of Ukraine. 